\title{
Understanding E-retailers' Satisfaction to Express Delivery Companies (EDC): The Case of China
}

\author{
Zhang Yunchuan \\ School of Management \\ Wuhan University of Science and Technology, Center for \\ Service Science and Engineering Research, Wuhan University \\ of Science and Technology \\ Wuhan Hubei China \\ zhang.yc@live.com
}

\author{
Guo Xin \\ School of Management \\ Wuhan University of Science and Technology \\ Wuhan Hubei China \\ 781638408@qq.com
}

\begin{abstract}
This research intends to investigate the relationship between the quality of the express delivery services, the satisfaction of e-retailers, and the satisfaction of e-retailers' customers. We developed a SERVQUAL model. 185 valid questionnaires are used to evaluate the quality of the delivery services, and to capture the satisfaction indices the e-retailers rate their delivery service providers. The customers' self-report satisfaction indices about the delivery services, which showing on e-retailers Taobao pages, are mapped to corresponding delivery companies the e-retailers have chosen. Correlation analysis shows that the service quality which measured in $\mathbf{5}$ dimensions, i.e. Tangibility, Reliability, Assurance, Empathy, Responsiveness, has a positive effect on E-retailer satisfaction. Unexpectedly, we find no significant relationship between the satisfaction of e-retailers' customers and that of the e-retailers. It implies e-retailers overlook their customers' experience with delivery services. Probably they care more about other factors, e.g. cost, approachability, while evaluate the express delivery providers.
\end{abstract}

Keywords-Service quality, SERVQUAL model, the satisfaction of e-retailers' customers, E-retailer satisfaction

\section{INTRODUCTION}

According to the data of the statistical bulletin for the development of the postal industry in 2015 that states by State Post Bureau of The People's Republic of China, the total number transactions of express delivery business had achieved 2067 million pieces, and the total revenue of express delivery business had achieved 27696 million RMB. Express delivery business has high profits obviously. There are three main types companies to cover parcel delivery business nationwide in China. They are state-operated companies, private-operated companies and foreign investment operated companies respectively. State-operated firm are EMS (China Post), China Air Express (CAE) and China Rail Express (CRE), with nationwide network in Chinese parcel delivery market. Foreign investment operated firms are DHL, FEDEX, UPS, TNT etc. Private-operated firms have big numbers and most intense competition, just like Sto express, Zto express, Yto express etc. Private companies including foreign companies delivered $70.6 \%$ of total parcels. Because there is no perfect national legislation regulated EDC in China, they had a 36\% average annual growth rate from 2006 to 2013. So it's fundamental survival for EDC to get more customers. It's crucial to study customer satisfaction to EDC. It can offer constructive strategies for EDC to attract more customers.

EDC have two kinds of customers mainly, just enterprise and personal customers, their representatives are e-retailers and e-retailers' customers respectively[1]. With the speedy development of e-commerce technique and logistics, online shopping has become more and more popular around in China. E-retailers have become the largest customer groups, it's especially important to study e-retailer satisfaction to EDC. With these developments, there are almost no papers study e-retailers satisfaction to EDC by service quality theory perspective and the relationship between e-retailer satisfaction and the satisfaction of e-retailers' customers. We attempt to view e-retailer satisfaction to EDC using SERVQUAL model. And highlight the effect of the satisfaction of e-retailers' customers on e-retailer satisfaction.

In this study, by applying SERVQUAL model in the context of e-retailers, we expect to provide a triadic model on EDC service quality, e-retailer satisfaction and the satisfaction of e-retailers' customers. Meanwhile, after analyzing the data, our finding will be helpful for EDC to learn how to attract e-retailers' attention in raising their service quality and tell the relationship between e-retailer satisfaction and the satisfaction of e-retailers' customers. From EDC perspective, they should not only try to satisfy e-retailers' customers as they make selection decisions as well, but also try to tell the importance between e-retailer satisfaction and the satisfaction of e-retailers' customers. Therefore, we will give suggestions for EDC on how to attract more e-retailers as their customers. Moreover, we carried out research in China; we will highlight some insights about Chinese market for EDC and e-retailers.

The rest of the paper is organized as follows: Section 2 reviews the studies related to express delivery companies (EDC), customer satisfaction and SERVQUAL model. Section 3 describes the conceptual model and hypotheses developed for the study. Section4 explains the research methodology adopted in this study to validate the conceptual model. Section 5 discusses the major findings. Section6 summarizes our study and suggests future directions 


\section{LITERATURE REVIEW}

\section{A. Express Delivery Companies(EDC)}

There are lots of literatures about third-part logistics, early 3PLs is referred as suppliers of logistics outsourcing. 3PLs, as a new business form, has been developing since the 1990s. At present, in the US, about $42 \%$ of the companies have implemented logistics outsourcing. Nowadays, 3PLs has become universal in China. EDC is fierce in competition at present, how to strengthen the management inside companies, it is primary problem in front of policy maker of each company in charge of express service to improve the competitiveness in the market of companies constantly. So this paper focuses on the research of customer satisfaction of EDC.

\section{B. The relationship between EDC and customer satisfaction}

Previous researches to study the relationship between customer and EDC have three parts mainly: First, Researches studied customer satisfaction of EDC, but for customer satisfaction, they all have no defined clearly that it's the satisfaction of e-retailers' customers or e-retailers satisfaction, maybe it's just contained the satisfaction of e-retailers' customers[2]. Second, Researches studied e-retailers selection of EDC mainly based on supplier selection on service supply chain by using analytic hierarchy process and so on[3]. They all have no study supplier satisfaction by service quality theory perspective. Jie YU distinguish customer as e-retailers and the e-retailers' customers. It explained the relationship among EDC, the e-retailers' customers and e-retailers, and focus on e-retailers selection of EDC to ensure timely and efficient delivery to consumers[1]. This research believed that e-retailers select EDC is to ensure the satisfaction of e-retailers' customers.

\section{Customer satisfaction}

Customer satisfaction is a business term that describes the measurement of goods or services provided by the company to ensure that their customers' expectation is achieved. Customer satisfaction is becoming an important research direction and has been researched in many different areas by researchers. Some researchers studied customer satisfaction of EDC, but for customer satisfaction, they all have no defined clearly that it's consumer satisfaction or e-retailers satisfaction, maybe it's just contained consumer satisfaction. Some researchers studied e-retailers selection of EDC mainly based on supplier selection on service supply chain by using analytic hierarchy process and so on[4,5,6]. They all have no study supplier satisfaction by service quality theory perspective. So in this paper, the customer satisfaction will be divided into the satisfaction of e-retailers' customers and e-retailer satisfaction. The satisfaction of e-retailers' customers used as a regulated variable, analysis the regulate impact of service quality on e-retailer satisfaction.

\section{SERVQUAL model}

Service quality plays a vital role in the service industry; it has been studied in many different ways by researchers. Many researchers think customers are the sole judges of service quality. Just like Gronroos (1978) think service quality is made of two parts, which are technical quality and functional quality; Kasper et al. (1999) claim service quality is made of the service process and the service organization that can satisfy the expectations of the user. There are many researchers evaluate customer perceptions by service quality theory in different areas[2]. Such as international express service, airline cargo service, airline service, Chinese e-retailing service and so on. However, there are a few opinions stated that the impact of EDC service quality on e-retailer satisfaction. Many studies have identified that the SERVQUAL model of Parasuraman et al., 1985[7,8], It has been applied in many areas. This paper shows the five crucial dimensions that leads to model of service quality developed and concluded by Parasuraman et al (1985) and been added according to private-operated express service companies service feature. This paper puts forward the following five crucial dimensions:

Tangible: EDC's physical facilities, equipment and communication materials;

Responsiveness: EDC's abilities to perform the promised service dependably and accurately;

Assurance: EDC's abilities to Provide prompt service and the willingness to help customers;

Reliability: EDC's knowledge, courtesy and ability to convey trust and confidence;

Empathy: The ability of EDC in providing care and attention individually to each customer.

\section{CONCEPTUAL MODEL AND HYPOTHESIS DEVELOPMENT}

Jie et al. elaborated the relationship among EDC, e-retailer and the e-retailers' customers in the article focuses on the choice of e-retailers, nevertheless, this paper will emphasize the satisfaction of e-retailers[9]. In this paper, based on the classic SERVQUAL model, research the impact of service quality on e-retailer satisfaction and the relationship of the satisfaction of e-retailers' customers and e-retailer satisfaction. Jie YU et al (2015) distinguish customer as e-retailers and the e-retailers' customers. It explained the relationship among EDC, the e-retailers' customers and e-retailers, and focus on e-retailers selection of EDC to ensure timely and efficient delivery to the e-retailers' customers[1]. This research believed that e-retailers select EDC is to ensure the satisfaction of e-retailers' customers. To sum up, this paper puts forward the following hypothesis and propose structural model (Fig. 1):

Hypothesis 1: Tangibility has a positive effect on E-retailer satisfaction;

Hypothesis 2: Reliability has a positive effect on E-retailer satisfaction;

Hypothesis 3: Assurance has a positive effect on E-retailer satisfaction;

Hypothesis 4: Empathy has a positive effect on E-retailer satisfaction;

Hypothesis 5: Responsiveness has a positive effect on E-retailer satisfaction;

Hypothesis 6: The satisfaction of e-retailers' customers has a positive effect on E-retailer satisfaction 

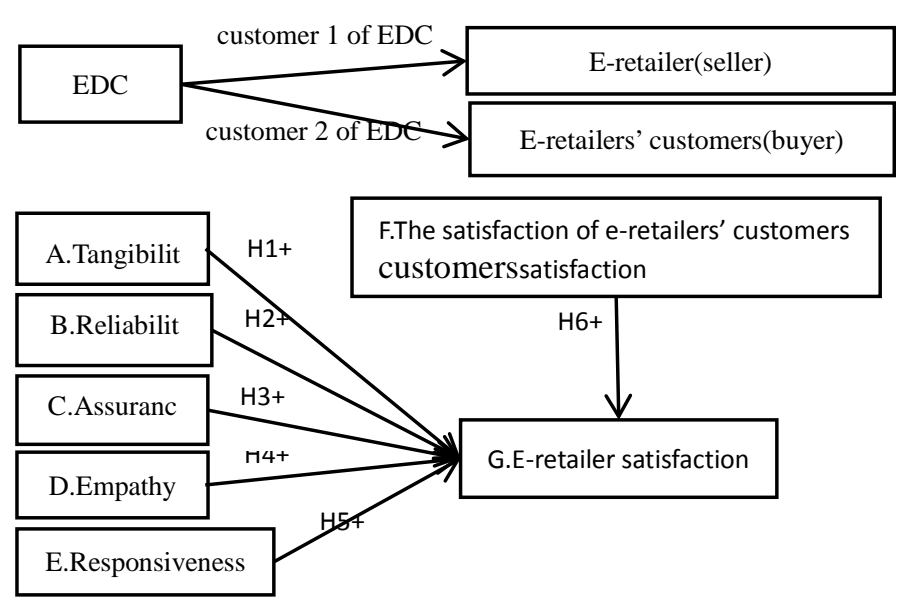

Fig. 1. The Conceptual Model

\section{RESEARCH DESIGN}

In order to ensure the reliability and validity of the scale, it is based on the maturity scale of the existing literature at home and abroad, and has been revised by the customer survey. This measure was based on 10 items which attribute to the five dimensions of the SERVQUAL model developed by Parasuraman et al. (1985; 2011) with appropriate changes to make the items more relevant to the present study. Responses to these items were made on a five-point Likert format which ranged from 1 ="strongly disagree” to 5 ="strongly agree".

The target population of this study is people who are Wechat retailers or Taobao retailers. The survey was conducted from February to March 2017. On the one hand, about the research for the relationship between service quality and e-retailer satisfaction, we collect data from e-retailers on their evaluations of PESF, it's helpful for e-retailers to assess their cooperative PESF in service quality. On the other hand, about the research for the relationship between consumer satisfaction and e-retailer satisfaction, we collect data from customer ratings score of logistics services on Taobao. As this is a pilot study, a non-probability sampling was used. By using the method of questionnaire, based on the questionnaire star (www.sojump.com) made questionnaire and send the link address to e-retailers' customer service provider. 185 valid questionnaires were returned, measurement items and the number of valid questionnaires amounted to 1:12.3.

\section{Result AnAlysis}

\section{A. Validity \& Reliability Analysis}

Exploratory factor analysis of all items of the questionnaire by SPSS20.0. The KMO value of the questionnaire items was 0.726, which was more than 0.7, and the value of Bartlett test was 0.000 , which was less than 0.01 , which was in accordance with the requirements of the research, and could be used for factor analysis. According to the results of factor analysis, there are six factors of the questionnaire measurement items, the characteristic roots of these seven factors are 5.166, 1.861, $1.272,1.019,0.807,0.657$, the variance percentage of the explained factors are 39.739\%, 14.312\%, 9.783\%, 7.835\%, $6.205 \%$, 5.051\%, cumulative can explain $82.926 \%$ of total variance. Through the comparative analysis with measurement items and sort out the factor 1 is responsiveness, factor 2 is assurance, factor 3 is e-retailer satisfaction, factor 4 is empathy, factor 5 is tangibility, and factor 6 is reliability. The result showed good construct validity of questionnaire. As shown in Table 2, the reliability of the scale is investigated by Cronbach's Alpha coefficient method. In general, Cronbach's Alpha $>0.6$ indicates better results. The reliability values of the survey variables and the overall scale were greater than 0.6 , which indicated that the design of the survey items in the questionnaire was good, and there was a good consistency between the items. As shown in Table I.

TABLE I RELIABILITY STATISTICS

\begin{tabular}{lll}
\hline Variable & Cronbachs Alpha & items \\
\hline Tangibility & .785 & 2 \\
Reliability & .684 & 2 \\
Assurance & .798 & 2 \\
Empathy & .657 & 2 \\
Responsiveness & .836 & 2 \\
E-retailer satisfaction & .778 & 3 \\
overall scale & .863 & 13 \\
\hline
\end{tabular}

B. The relationship of service quality and e-retailer satisfaction

Carrying out Pearson correlation analysis of tangibility, reliability, assurance, empathy, responsiveness and e-retailer satisfaction respectively by SPSS20.0. If there is a significant correlation between the 0.01 levels (bilateral), indicating the strong correlation between the two variables. The results showed that: tangibility has a positive effect on e-retailer satisfaction; reliability has a positive effect on e-retailer satisfaction; assurance has a positive effect on e-retailer satisfaction; empathy has a positive effect on e-retailer satisfaction; responsiveness has a positive effect on e-retailer satisfaction. Supporting hypothesis H1, H2, H3, H4, H5. As shown in Table II.

TABLE II CORRELATIONS OF VARIABLES

\begin{tabular}{|c|c|c|}
\hline & & G \\
\hline \multirow{3}{*}{ A } & Pearson correlation & $.428^{* *}$ \\
\hline & Significant (bilateral) & .000 \\
\hline & $\mathrm{N}$ & 184 \\
\hline \multirow{3}{*}{ B } & Pearson correlation & $.558 * *$ \\
\hline & Significant (bilateral) & .000 \\
\hline & $\mathrm{N}$ & 184 \\
\hline \multirow{3}{*}{$\mathrm{C}$} & Pearson correlation & $.629 * *$ \\
\hline & Significant (bilateral) & .000 \\
\hline & $\mathrm{N}$ & 184 \\
\hline \multirow{3}{*}{$\mathrm{D}$} & Pearson correlation & $.601 * *$ \\
\hline & Significant (bilateral) & .000 \\
\hline & $\mathrm{N}$ & 184 \\
\hline \multirow{3}{*}{$\mathrm{E}$} & Pearson correlation & $.423 * *$ \\
\hline & Significant (bilateral) & .000 \\
\hline & $\mathrm{N}$ & 184 \\
\hline
\end{tabular}




\section{The relationship of the satisfaction of e-retailers' customers and e-retailer satisfaction}

Carrying out Pearson correlation analysis of consumer satisfaction and e-retailer satisfaction respectively by SPSS20.0. If there is a significant correlation between the 0.01 levels (bilateral), indicating the strong correlation between the two variables. The results showed that: consumer satisfaction has no effect on e-retailer satisfaction. Overthrowing hypothesis H6. As shown in Table III.

\section{TABLE III CORRELATIONS OF VARIABLES}

\begin{tabular}{|c|c|c|}
\hline \multicolumn{2}{|c|}{} & $\mathrm{G}$ \\
\hline \multirow{3}{*}{ F } & Pearson correlation & -.117 \\
\cline { 2 - 3 } & Significant (bilateral) & .114 \\
\cline { 2 - 3 } & $\mathrm{N}$ & 184 \\
\hline
\end{tabular}

Based on the above data analysis, supporting hypothesis H1, H2, H3, H4, H5, Overthrowing hypothesis H6. The modified model as shown in Fig. 2

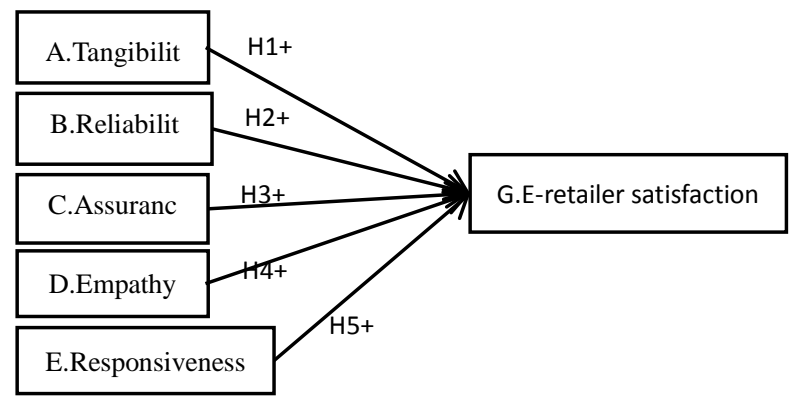

Fig. 2. The modified Model

\section{CONCLUSION}

In this study, based on the SERVQUAL model, research the relationship between five dimensions of service quality namely tangibility, reliability, assurance, empathy, responsiveness and the two types of customer satisfaction namely consumer satisfaction and e-retailer satisfaction respectively. E-retailer customer service providers and WeChat business as a research sample, using correlation analysis of SPSS, examining the logical relationship among tangibility, reliability, assurance, empathy, responsiveness, consumer satisfaction and e-retailer satisfaction. The empirical results show that tangibility has a positive effect on e-retailer satisfaction; reliability has a positive effect on e-retailer satisfaction; assurance has a positive effect on e-retailer satisfaction; empathy has a positive effect on e-retailer satisfaction; responsiveness has a positive effect on e-retailer satisfaction. Consumer satisfaction has no effect in the effect on e-retailer satisfaction.

The findings of this study have significance to the practice of management of express company, and overthrew the views of Jie YU who believed that e-retailers select PESF is to ensure consumer satisfaction. This paper think consumer satisfaction just has no effect on e-retailer satisfaction. This means that if PESF want to improve the satisfaction of e-retailer, the focus is to take measures in the five dimensions of service quality or other factors such as prices, rather than relying on improving the consumer satisfaction.

\section{REFERENCES}

[1] Jie YU,N Subramanian, K Ning, D Edwards(2015)Product delivery service provider selection and customer satisfaction in the era of internet of things: A Chinese e-retailers' perspective ,International Journal of Production Economics ,159 1,04-116

[2] Li, F., Li, L., Jin, C., Wang, R., Wang, H., \& Yang, L. (2012). A 3PL supplier selection model based on fuzzy sets. Computers \& Operations Research, 39(8), 1879-1884.

[3] R Wang, Shu-Li,H Y Lin, L M Tseng(2011)Evaluation of customer perceptions on airline service quality in uncertainty, Procedia - Social and Behavioral Sciences ,25,419-437

[4] N Subramanian, A Gunasekaran, J Yu,J Cheng, K Ning(2014)Customer satisfaction and competitiveness in the Chinese E-retailing: Structural equation modeling (SEM) approach to identify the role of quality factors ,Expert Systems with Applications An International , 41(1),69-80

[5] WANG Jianbin, HUANG Wengu, CHEN Bozhi(2010)Empirical Study of Service Quality, Customer Satisfaction and Administrator's Perception for Automobile Service Workshop ,Science and Technology Management Research ,1,274-288

[6] XU Haojie(2010)Empirical Study of SERVQUAL service quality evaluation and customer satisfaction of logistics service, China Storage \& Transport,5,81-82

[7] A Parasuraman, A V Zeithaml, L L Berry(1985)A Conceptual Model of Service Quality and Its Implications for Future Research ,Journal of Marketing,49(4),41-50

[8] J Munusamy, S Chelliah, W H Mun(2010)Service Quality Delivery and Its Impact On Customer Satisfaction in The Banking Sector in Malaysia, International Journal of Innovation, Management and Technology, 1(4),398-404 